\title{
Prof. John Chabot: working hard and asking important questions, but also keeping focused
}

Submitted Nov 04, 2019. Accepted for publication Nov 06, 2019.

doi: $10.21037 /$ hbsn.2020.03.18

View this article at: http://dx.doi.org/10.21037/hbsn.2020.03.18

\section{Expert's introduction}

Prof. John Chabot (Figure 1) received his medical degree from Dartmouth College School of Medicine and completed a residency in General Surgery at Columbia Presbyterian Medical Center and a fellowship in Surgery at Dartmouth-Hitchcock Medical Center. He joined New York-Presbyterian/Columbia in 1983 and has since become Professor of Surgery and Executive Director of the Pancreas Center and Chief of Gastrointestinal/Endocrine Surgery. Prof. Chabot's clinical interest is focused on the prevention, treatment, and cure of cancers involving the gastrointestinal tract (especially pancreatic cancer) and other areas of surgical oncology such as the surgical treatment of thyroid cancer and mesothelioma of the peritoneum. He has published extensively in leading medical journals including Pancreas, Fournal of Clinical Oncology, Fournal of Gastrointestinal Surgery, and other notable publications. $\mathrm{He}$ also actively leads Columbia Doctors in responding to the challenges associated with rapid innovation, advancing technology, and the highly informed patient. Prof. Chabot has received numerous awards during his career, including the Jerry Gliklich Practitioner of the Year Award, Teaching Award in Surgery for Excellence in Teaching and Mentoring, and has been named multiple times as one of New York Magazine's Top Doctors.

\section{The interview}

HBSN: What made you decide to engage in the study of pancreatic cancer?

Prof. Chabot: It is a difficult question. I don't have a good answer. I think the best answer is because when I started studying, it was very difficult and it was a big challenge for us.

\section{HBSN: What do you think of the development of this field in the future?}

Prof. Chabot: I think it will be a very exciting time, and my

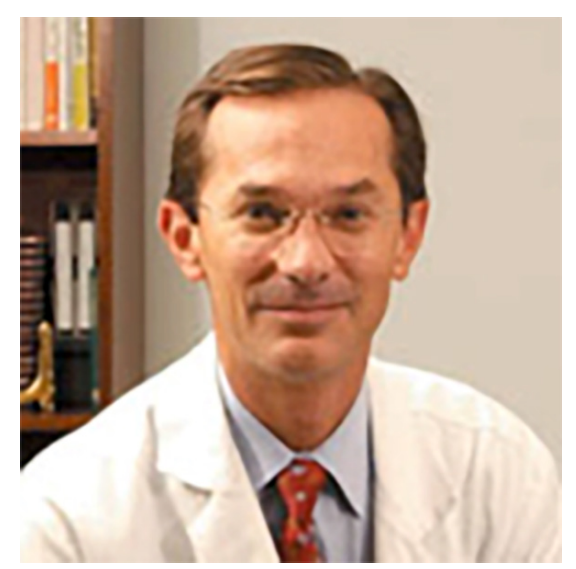

Figure 1 John Chabot.

goal today is to try to communicate that. The idea is that doctors with different specialties can support each other, and make the sum of their efforts better than the individual parts. And I think this is why we are here today.

\section{HBSN: Can you talk about some recent advances in the therapy of pancreatic cancer?}

Prof. Chabot: No question is more important than the improvement of chemotherapy, the choice of chemotherapy for individual patients, and the ability to deliver that chemotherapy safely.

\section{HBSN: Would you also mind sharing some of difficulties that you have faced in research or clinical work?}

Prof. Chabot: The important challenge in doing the kind of work that I have been doing is being able to have departments work closely with each other. Most universities are built around departments working independently of each other. And I think what cancer patients really need are doctors from different departments working closely together. One of my proudest achievements is having all 
pancreatic doctors from every different department living and working on the same floor of the hospital. Instead of having just surgeons, just oncologists, just radiologists, we all work on the same floor.

HBSN: Being such a successful professor, what do you think is the key to success?

Prof. Chabot: I think, obviously, working hard and asking important questions, but also keeping focused. Understanding where you want to go, finding what your question is going to be, and sticking with that question, even when it becomes difficult.

\section{HBSN: When did you first hear about our journal, HBSN?}

Prof. Chabot: Oh, that must have been 6 or 7 years ago. I am not sure exactly when, but quite a long time ago.

\section{HBSN: So what do you see in HBSN's future?}

Prof. Chabot: I anticipate being your reviewer. So, I hope to help it to develop.

\section{HBSN: I do bope we can have a productive collaboration. Thank you.}

\section{Acknowledgments}

I would like to express my sincere gratitude to Prof. John Chabot for accepting our interview. I would also like to thank the editor of $H B S N$, for her guidance on this interview.

Funding: None.

\section{Footnote}

Provenance and Peer Review: This article was commissioned by the Editorial Office, Hepatobiliary Surgery and Nutrition. The article did not undergo external peer review.

Conflicts of Interest: All authors have completed the ICMJE uniform disclosure form (available at https://hbsn.amegroups. com/article/view/10.21037/hbsn.2020.03.18/coif). The authors have no conflicts of interest to declare.

Ethical Statement: The authors are accountable for all aspects of the work in ensuring that questions related to the accuracy or integrity of any part of the work are appropriately investigated and resolved.

Open Access Statement: This is an Open Access article distributed in accordance with the Creative Commons Attribution-NonCommercial-NoDerivs 4.0 International License (CC BY-NC-ND 4.0), which permits the noncommercial replication and distribution of the article with the strict proviso that no changes or edits are made and the original work is properly cited (including links to both the formal publication through the relevant DOI and the license). See: https://creativecommons.org/licenses/by-ncnd/4.0/.

(Science Editor: Ziyan Cai, HBSN, editor@thehbsn.org)

Cite this article as: Cai Z. Prof. John Chabot: working hard and asking important questions, but also keeping focused. HepatoBiliary Surg Nutr 2020;9(2):269-270. doi: 10.21037/ hbsn.2020.03.18 